\title{
Characteristics, Technology Capabilities, and Experiences of In-Service Teachers on the Use of Online/Blended Learning at a Tertiary Institution in Jamaica
}

\author{
Cynthia Onyefulu ${ }^{1}$, Carmel Roofe ${ }^{2}$ \\ ${ }^{1}$ Faculty of Education \& Liberal Studies, University of Technology, Jamaica \\ ${ }^{2}$ Faculty of Humanities \& Education, The University of the West Indies, Mona, Jamaica \\ Email: *conyefulu@gmail.com
}

How to cite this paper: Onyefulu, C. and Roofe, C. (2019) Characteristics, Technology Capabilities, and Experiences of In-Service Teachers on the Use of Online/Blended Learning at a Tertiary Institution in Jamaica. Open Access Library Journal, 6: e5147. https://doi.org/10.4236/oalib.1105147

Received: December 27, 2018

Accepted: January 19, 2019

Published: January 22, 2019

Copyright $\odot 2019$ by author(s) and Open Access Library Inc.

This work is licensed under the Creative Commons Attribution International License (CC BY 4.0).

http://creativecommons.org/licenses/by/4.0/

\section{(c) (i) Open Access}

\begin{abstract}
Students' success in the online environment seems to be inextricably linked to learner characteristics and experiences related to the use of information and communication technologies. An increasing number of in-service teachers are being encouraged to pursue continuing education via the use of these technologies. This study examined learner characteristics, experiences, and technological capacities possessed by 55 in-service teachers pursuing postgraduate studies using the online/blended learning approach. The paper was also aimed at determining if there are differences in the views expressed by the male and female in-service teachers on learner characteristics, experiences, and technological capacities. Five research questions guided the study. A questionnaire was used to collect data, and descriptive and inferential statistics were used for the analysis. The findings indicated that a majority of the in-service teachers possessed the characteristics and technological capacities needed to succeed in the online learning environment. The findings also showed that most of the in-service teachers had the characteristics needed to do online/blended learning, had basic technology capabilities needed to succeed in an online/blended learning programme, and the in-service teachers had different experiences with the online/blended learning approach. Recommendations were towards making the in-service teachers' experiences more desirable.
\end{abstract}

\section{Subject Areas}

Education 


\section{Keywords}

Online/Blended Learning, In-Service Teachers, Learner Characteristics, Technological Capacities, Online Learner Experiences

\section{Introduction}

The process of education in most contexts is continuously being re-constructed and redefined. One of the innovations that continue to drive this re-construction and redefinition is the introduction of technology in education. Technology through online/blended learning is being used to shape how learning occurs at all levels of the education system and for all who participate. As a result, online learning is now a popular model of learning, particularly due to the number of persons seeking to advance their knowledge and skills [1]. The Sloan Consortium studies by Allen and Seaman ([2] [3] [4] have shown a steady increase and demand for online learning over the years. This view was also expressed by Kuh, Kinzie, Schuh, and Whitt [5] who noted the increase in demand for online education. According to Kentnor [6], "Online education is no longer a trend. Rather, it is mainstream" (p. 21). To meet the growing demand, several institutions now offer either fully online education or a combination of face-to-face and online learning ([1] [7]).

One area of the education system that technology is continuously being used to redefine in Jamaica is teacher professional development. According to Kokoc, Ozlu, Cimer, and Karal [8], professional development of teachers is in an important component of educational reform and improvement. Fullan [9] in support of this view noted that educational change is dependent on what teachers do and think. It is expected that through successful in-service teacher development programmes the desired outcomes for education can be achieved. More specifically, it is assumed that if teachers are exposed to quality usage of the technology, then they will in return use the technology to improve their students' outcomes.

Technology usage in the professional development of teachers ranges from the focus of technologies in teachers instructional practices to the use of Learning Management Systems to provide learning for teachers (Perraton et al., 2001, as cited in Anderson \& Glen [10] [11]). Based on the need to increase access to education and training for in-service teachers, and the view that exposure to technology should enable teachers to see the need to implement technology in their classrooms, teacher education institutions have sought to include the use of technology in professional development courses. This has led to the use of online learning as one of the means of conducting professional development for in-service teachers due to wide access to learning when technology is used, and flexibility in the delivery of higher education and lifelong learning Hunt [12] and the European Commission [13] supported the type of continuing professional 
development training. Online learning, therefore, continues to infiltrate discourse regarding programme offerings in teacher-education institutions.

In Jamaica, graduates who are either already teaching without a teaching certificate or those who wish to join the teaching profession enroll in postgraduate teacher training programmes. This study was conducted in one of such institutions which offer postgraduate programmes in teacher education. This postgraduate diploma in education (PDE) programme began in the 1990s and courses were delivered through face-to-face model during the summer, and it is designed to last for two years. However, in 2013, recognizing the importance of lifelong learning and the need to need the needs of the students, some aspects of the programme were offered online using the Moodle platform. This hybrid model of delivery is used by several institutions around the world to meet the learning needs of students ([1] [14]).

\subsection{Purpose of the Study}

The purpose of this study was to examine learner characteristics, experiences, and technological capacities possessed by in-service teachers pursuing postgraduate studies using the online/blended learning approach at the postgraduate levels at a teacher training institution in Jamaica. The study was also aimed at determining if there were differences in the views expressed by the in-service teachers on learner characteristics, experiences, and technological capacities.

\subsection{Research Questions}

The following research questions guided the study:

1) What percentage of the in-service teachers possessed the required characteristics needed for online/blended learning?

2) To what extent are there differences in the views of the in-service teachers in the secondary and tertiary tracks of the PDE programme on the technology capabilities needed for online/blended learning?

3) To what extent are there differences in the interest of the in-service teachers in the secondary and tertiary tracks of the PDE programme on online/blended learning approach?

4) To what extent are there differences in the views expressed by the male and female in-service teachers on learner characteristics, technology capabilities, and experiences of online/blended learning approach?

5) What are the learning experiences and expectations of the in-service teachers on the online/blended learning approach?

\subsection{Delimitations of the Study}

The study was delimited in two ways. First, only in-service teachers pursuing the postgraduate diploma in education in one institution between 2014/15 and 2015/16 academic year were used in the study. Second, only the characteristics, technology capabilities, and experiences of these in-service teachers were ex- 
amined within the context of courses taught using the online/blended (online \& face-to-face) learning approach through the Learning Management System known as Moodle.

\section{Literature Review}

A search of internet resources using Google Scholar, and databases such as EBSCOhost, and Emerald was done by using keywords such as online/blended learning, in-service teachers, learner characteristics, technological capacities, and online learner experiences. The findings of these searches are presented in this session under two main sub-headings: Technology and Education, and the Use of Online/Blended Learning Approach.

\subsection{Technology and Education}

Online learning is defined as "the use of information and computer technologies to create experiences [15] (p. 1). However, not all programmes are fully online. As noted by Allen and Seaman [4], technology-based learning may be offered as in a number of ways, including fully online, blended/hybrid, and web-facilitated. In this study, both online and blended learning approaches were used in the PDE programme. According to Allen and Seaman [4], in blended/hybrid learning " $30 \%$ to $79 \%$ " of the content is delivered online, because of the blend of online and face-to-face delivery approaches.

Brunto, Brown, Costello, Delaney, Fox, and Galvin [16] cited the Higher Education Authority (HEA, 2012) definition of flexible learners as "those students who are in part-time, distance, e-learning, and in-service education" (p. 10). However, in their practice report, Brunto, Brown, Costello, and Farrell [17] cited the definition of a flexible learner as "an adult engaged in part-time or online distance learning" (p. 2). These definitions fit the description of the in-service teachers in the PDE programme.

As postulated by Ghavifer et al. [18], and Caldwell and Spinks [19], since the mid-1990s developments in Information and Communication Technologies (ICT) have impacted on schooling and have transformed learning and teaching. These developments have affected the way courses are taught and delivered at all levels of the education system internationally. These developments have also created new opportunities for pursuing learning. According to Green, Robelia and Hughes [20], learners have more choices about how and where to spend their time rather than they did 10 years ago. Several researchers ([18] [21] [22]) have also indicated that more use of ICT's in the classroom would lead to better engagement and preparation of students. According to Albion [23], teacher education programmes need to prepare students for integrating ICTs in their teaching as well as skills in the use of ICTs. In a report published by the United Nations Educational, Scientific and Cultural Organization (UNESCO) [24] three approaches for technology integration in teacher professional development ranging from technology literacy to knowledge deepening through knowledge 
creation were suggested.

Within Jamaica the VISION 2030 ICT sector plan, it was indicated that the country aims to develop and institutionalize a teacher education system that provides a technology integrated learning environment and graduates those who are equipped to prepare students with the requisite skill sets [25]. This indicates that as a country, Jamaica is serious about teachers use and possessions of ICT skills as a means of providing quality education.

\subsection{The Use of Online/Blended Learning Approach}

Blended learning is a practice that combines teaching methods from face-to-face classroom setting and online learning environments. According to Eduviews [26], the blended learning instructional model is an increasingly common instructional practice across the curriculum for students and teachers alike. Blended learning is seen as the model best suited to provide the most appropriate experience for students' success. Although the use of blended learning is increasing and continues to infiltrate every sphere of education, Friedman [27] noted that it should not be taken for granted that this easily translates to students' success. Since the online component of blended programmes represents a shift from traditional instructional experience, it is imperative that monitoring of students' experiences and characteristics be included in any programme implemented. As postulated by Burge [28] persons enter the online learning environment with different skill levels hence it is recommended that before a student takes online classes information must be solicited about the skill levels of the students. This will provide data on the students' readiness for the online environment.

According to Kim and Bonk [29], a review of various studies indicated that student satisfaction, student achievements, and faculty support are important means of assessing the quality of online learning. Additionally, from research conducted with students enrolled in an online course in an Australian university, Volery and Lord [30] noted that technology, the instructor and students previous use of technology were critical success factors in online facilitation. To further aid the discussion on success in the facilitation of online learning, Pelz [31] offered three guiding principles of pedagogy for educators. These principles were also supported by the Institute for Higher Education [32] and Tobin [33]. They are further discussed below.

The first principle Pelz [31] noted is to allow the student to do most of the work. This may be achieved through student-led discussion, peer assistance, student grading their assignments, case study analysis, and students' discussion of web resources. This principle is carried out on the assumption that the more quality time students spend engaged with the content, the more learning takes place.

The second principle offered by Pelz [31] is interactivity. He was of the view that interactivity is the heart and soul of learning in this environment, but interactivity must go beyond simple student discussion. Pelz [31] was also of the 
view that interaction can take place in different ways, such as with the professor, each other, text, and with the internet in small groups or teams or one and one.

The final principle suggested by Pelz [31], was to strive for presence. According to Pelz, presence may occur in three forms: social presence, cognitive presence, and teaching presence. He indicated that in an online environment participants must present themselves as real people who are affective, interactive, and cohesive. Further to that cognitive presence is felt through continuous discussion, construction of meanings and the building of a community of inquiry. Teaching presence then allows for the facilitation of social and cognitive process to achieve personal and educationally worthwhile outcomes.

\section{Methods}

\subsection{Design and Sampling}

A descriptive quantitative (survey research) design was used for the study. According to Leedy and Ormrod [34] and Gall, Gall and Borg [35], this type of research is used to gain an understanding of a past or present situation. It was for this reason the design was used to examine the characteristics and experiences of in-service teachers in a postgraduate diploma in education programme offered through the blended approach.

The participants in the study were in-service teachers registered in the postgraduate programmes. The sample size was 59 . No sampling was done due to the small number. Of the 59 administered questionnaires, 55 (93.2\%) was returned and used in the study. The response rate of approximately $93 \%$ and is considered to be very good [36]. According to Leedy and Ormrod [34], when the population is small, that is, less than 100, there is no need to sample. For this reason, all the in-service teachers were asked to participate in the study. See Table 1 for the description of the participants.

As shown in Table 1, two groups of persons participated in the study (26 in the secondary \& 29 in the tertiary track of the programme). Of the 55 who participated, 22 (40.0\%) were male, and 33 (60.0\%) were female. This showed that the students were predominantly females. Eighteen $(32.7 \%)$ of the respondents were 30 years and below. This is followed by 21 (38.2\%) who were between 31 and 40 years, $10(18.2 \%)$ were between 41 and 50 years, and $6(10.9 \%)$ were above 50 years. All 55 participants had experienced the blended learning approach. Of the 55 respondents who indicated their work experience, $6(10.9 \%)$ had less than one year of teaching experience, $30(54.5 \%)$ had between one to five years teaching experience, $10(18.2 \%)$ had six to nine years teaching experience, and $9(16.4 \%)$ had over 10 years teaching experience.

\subsection{Data Collection}

Leedy and Ormrod [34] and Gall, Gall and Borg [35] recommended the use of a questionnaire as one of the data collection methods for descriptive studies. Given the purpose of the study, a questionnaire was used to collect data. 
Table 1. Demographic characteristics of study participants.

\begin{tabular}{lccc}
\hline \multicolumn{1}{c}{ Characteristics } & \multicolumn{2}{c}{ Teachers } & Total \\
\cline { 2 - 3 } & $\begin{array}{c}\text { Secondary } \\
(n=26)\end{array}$ & $\begin{array}{c}\text { Tertiary } \\
(n=29)\end{array}$ & \\
\hline Gender: & $9(16.4 \%)$ & $13(23.6 \%)$ & $22(40.0 \%)$ \\
Male & $17(30.9 \%)$ & $16(29.1 \%)$ & $33(60.0 \%)$ \\
Female & & & \\
Age Range: & $12(21.8 \%)$ & $6(10.9 \%)$ & $18(32.7 \%)$ \\
30 years \& under & $8(14.5 \%)$ & $13(23.6 \%)$ & $21(38.2 \%)$ \\
31 - 40 years & $5(9.1 \%)$ & $5(9.1 \%)$ & $10(18.2 \%)$ \\
41 - 50 years & $1(1.8 \%)$ & $5(9.1 \%)$ & $6(10.9 \%)$ \\
51 years \& over & $1(1.8 \%)$ & & $6(10.9 \%)$ \\
Teaching Experience: & $15(27.3 \%)$ & $15(27.3 \%)$ & $30(54.5 \%)$ \\
Less than 1 years & $4(7.3 \%)$ & $6(10.9 \%)$ & $10(18.2 \%)$ \\
1 - 5 years & $6(10.9 \%)$ & $63(5.5 \%)$ & $9(16.4 \%)$ \\
6 - 10 years & & & \\
Over 10 years & & $5.1 \%)$ & \\
\hline
\end{tabular}

The items in the questionnaire measured learner readiness for online learning, characteristics, technological capabilities, and experiences. The questionnaire had three sections. Section A contained five demographic items. Section B had 27 Likert-type items which were adapted with permission, from Dray and Miszkiewicz [37]. These items had a four-point Likert scale ( $1=$ strongly disagree, $2=$ disagree, 3 = agree, \& 4 = strongly agree), and were organized under three sub-scales. The first sub-scale was titled learner characteristics with 13 items. The second sub-scale was titled technology capabilities with seven items, and the last sub-scale called online/blended approach had another seven items. In Section $\mathrm{C}$, there were one close-ended and four open-ended items on online/blended learning experiences.

\subsection{Reliability and Validity}

Since the development of the questionnaire by Dray and Miszkiewicz [37], Dray, Lowenthal, Miszkiewicz, Ruiz-Primo, and Marczynski [38] conducted a two-phase study in which they developed, evaluated and validated the questionnaire for assessing students' readiness for online learning. The internal consistency for the two surveys by Dray et al. [38] was 0.662 , for survey one, and 0.802 for the second survey. However, coefficient alpha was used to determine the reliability of the questionnaire before it was used in Jamaica. This yielded an overall reliability coefficient of 0.851 for the 27 Likert-type items used in section B of the questionnaire. The acceptable values of Cronbach alpha is from 0.7 to 0.95 ([39] [40] [41]). See Table 2 for the internal consistency of the three subscales 
Table 2. Internal consistency for the subscales.

\begin{tabular}{ccc}
\hline Subscale & Number of Items & Alpha \\
\hline Learner Characteristics & 13 & 0.636 \\
Technology Capabilities & 7 & 0.865 \\
Online/Blended Approach & 7 & 0.795 \\
\hline
\end{tabular}

used in the questionnaire.

Factor analysis could not be used to estimate the construct validity of the questionnaire because the Kaiser-Meyer-Olkin (KMO) test used to determine the adequacy of using it was 0.550 . The rule of the thumb is from 0.8 ([42] [43]). For this reason, content validity was used to ensure that the items in the questionnaire cover the construct of interest, in this case, students' characteristics, technology capabilities, and experiences online/blended learning. This type of validity is determined through the use of a table of specifications and "the judgment of expert in the field" [44] (p. 15). In this case, an expert on distance/online education was asked examined the adequacy and relevance of all the items as it pertains measuring students' characteristics, technology capabilities, and experiences online/blended learning. The expert reported that the items in the questionnaire represented the domain of interest. According to Shekaran and Bougie (2010), "the more the scale items represent the domain of the concept being measured, the greater the content validity" (as cited in Mohajan, [44], p. 15).

\subsection{Data Analysis}

Negatively worded items in section B were re-coded before the data were entered into the SPSS program. The main method employed to analyze the data were descriptive (mean standard deviation \& percentages), and inferential statistics (independent samples $t$-test). The independent samples $t$-test was used to determine if there were any differences in the views expressed by the participants on the following three dimensions, namely, characteristics, experiences, and technological capabilities of online/blended learning approach.

\subsection{Ethical Considerations}

Permission was obtained from the PDE programme manager and the ethical committee of the faculty where the study was done granted the exemption before the study was conducted. All participants received an email which explained the purpose of the study and what was required of them to do (see the Appendix). On the questionnaire, the purpose of the study was also stated, voluntary participation, and their rights as participants. Furthermore, the participants were not exposed to any risks during the study since their role was only to respond to the questionnaire items. The data generated from the questionnaire remained anonymous when they were analyzed. 


\section{Results}

\subsection{In-Service Teachers' Characteristics}

Research Question One: What percentage of the in-service teachers possessed the required characteristics needed for online/blended learning?

Thirteen Likert-type items in the first subscale in Section B of the questionnaire were used to answer the above research question. The items were analysed using frequency and percentage (Table 3).

As shown in Table 3,100\% of the participants agreed that they were confident in their ability to excel in a university programme; $98 \%$ were comfortable responding to other people's ideas online; $96 \%$ each were responsible for their own education, comfortable working in alternative learning environments, work well in a group, and regulate and adjust their behavior to complete course requirements; 95\% each were good at completing tasks independently, give constructive and proactive feedback to others, and achieve goals set for themselves; $91 \%$ were comfortable expressing their opinions in writing to others; $89 \%$ were able to

Table 3. Descriptive statistics for the characteristics of in-service teachers.

\begin{tabular}{|c|c|c|c|c|}
\hline Characteristics & $\mathrm{SD}$ & $\mathrm{D}$ & A & SA \\
\hline $\begin{array}{l}\text { 1) I am confident in my ability to excel in a university } \\
\text { programme }\end{array}$ & - & - & $\begin{array}{c}14 \\
(26 \%)\end{array}$ & $\begin{array}{c}41 \\
(75 \%)\end{array}$ \\
\hline $\begin{array}{l}\text { 2) I give up easily when confronted with } \\
\text { technology-related obstacles }\end{array}$ & $\begin{array}{c}32 \\
(58 \%)\end{array}$ & $\begin{array}{c}16 \\
(29 \%)\end{array}$ & $\begin{array}{c}4 \\
(7 \%)\end{array}$ & $\begin{array}{c}3 \\
(6 \%)\end{array}$ \\
\hline 3) I believe I am responsible for my own education & - & $\begin{array}{c}2 \\
(4 \%)\end{array}$ & $\begin{array}{c}15 \\
(27 \%)\end{array}$ & $\begin{array}{c}38 \\
(69 \%)\end{array}$ \\
\hline $\begin{array}{l}\text { 4) I am comfortable working in alternative learning } \\
\text { environments }\end{array}$ & $\begin{array}{c}1 \\
(2 \%)\end{array}$ & $\begin{array}{c}1 \\
(2 \%)\end{array}$ & $\begin{array}{c}29 \\
(53 \%)\end{array}$ & $\begin{array}{c}24 \\
(43 \%)\end{array}$ \\
\hline $\begin{array}{l}\text { 5) I am comfortable expressing my opinion in } \\
\text { writing to others }\end{array}$ & - & $\begin{array}{c}5 \\
(9 \%)\end{array}$ & $\begin{array}{c}22 \\
(40 \%)\end{array}$ & $\begin{array}{c}28 \\
(51 \%)\end{array}$ \\
\hline 6) I work well in a group & - & $\begin{array}{c}2 \\
(4 \%)\end{array}$ & $\begin{array}{c}28 \\
(51 \%)\end{array}$ & $\begin{array}{c}25 \\
(45 \%)\end{array}$ \\
\hline 7) I am good at completing tasks independently & - & $\begin{array}{c}2 \\
(4 \%)\end{array}$ & $\begin{array}{c}24 \\
(46 \%)\end{array}$ & $\begin{array}{c}28 \\
(51 \%)\end{array}$ \\
\hline 8) I am comfortable responding to other people's ideas & - & $\begin{array}{c}1 \\
(2 \%)\end{array}$ & $\begin{array}{c}29 \\
(53 \%)\end{array}$ & $\begin{array}{c}25 \\
(45 \%)\end{array}$ \\
\hline $\begin{array}{l}\text { 9) I give constructive and proactive feedback to } \\
\text { others even when I disagree }\end{array}$ & - & $\begin{array}{c}3 \\
(6 \%)\end{array}$ & $\begin{array}{c}30 \\
(\%)\end{array}$ & $\begin{array}{c}22 \\
(40 \%)\end{array}$ \\
\hline $\begin{array}{l}\text { 10) I organize my time to complete course } \\
\text { requirements in a timely manner }\end{array}$ & $\begin{array}{c}1 \\
(2 \%)\end{array}$ & $\begin{array}{c}9 \\
(16 \%)\end{array}$ & $\begin{array}{c}31 \\
(56 \%)\end{array}$ & $\begin{array}{c}14 \\
(26 \%)\end{array}$ \\
\hline $\begin{array}{l}\text { 11) I regulate and adjust my behavior to complete } \\
\text { course requirements }\end{array}$ & - & $\begin{array}{c}2 \\
(4 \%)\end{array}$ & $\begin{array}{c}36 \\
(66 \%)\end{array}$ & $\begin{array}{c}17 \\
(30 \%)\end{array}$ \\
\hline 12) I achieve goals I set for myself & - & $\begin{array}{c}3 \\
(6 \%)\end{array}$ & $\begin{array}{c}32 \\
(58 \%)\end{array}$ & $\begin{array}{c}20 \\
(36 \%)\end{array}$ \\
\hline $\begin{array}{l}\text { 13) I understand the main ideas and important issues } \\
\text { of readings without guidance from the instructor }\end{array}$ & - & $\begin{array}{c}6 \\
(11 \%)\end{array}$ & $\begin{array}{c}33 \\
(60 \%)\end{array}$ & $\begin{array}{c}16 \\
(29 \%)\end{array}$ \\
\hline
\end{tabular}


understand the main ideas and important issues of readings without guidance from their instructors; and $87 \%$ will not give up easily when confronted with technology-related obstacles. Overall, a majority of the participants agreed that they possessed the characteristics needed for online/blended learning.

\subsection{In-Service Teachers' Technology Capabilities}

Research Question Two: To what extent are there differences in the views of the in-service teachers in the secondary and tertiary tracks of the PDE programme on the technology capabilities needed for online/blended learning?

To provide answers to the research question, the participants were asked to indicate their level of agreement to the seven Likert-type items that measured the in-service teachers' technology capabilities. See Table 4 for the mean and standard deviation values for each of the seven items.

As showed in Table 4, the mean values of the seven items ranged from 2.769 to 3.539 for teachers in the secondary track of the PDE programme, while the mean values for those in the tertiary track had mean values ranging from 3.241 to 3.689. These values showed that the participants were mostly in agreement in their responses. The standard deviation values ranged from 0.509 to 1.002 for the secondary track in-service teachers, and from 0.471 to 0.786 for the tertiary group. This showed that there were more variations in the responses of the secondary group. Noteworthy was item 19: It will easy to gain access to technical support when I need it, which had the lowest mean value for the secondary group.

Further, independent samples $t$-test was done to determine if there were any statistical differences between the two groups on the seven items. The results showed that there were significant differences in items $19 \& 20$. These were "It will easy to gain access to technical support when I need it," $t(53)=-2.185, p=$ $0.033)$; and "I am confident in using the computer-related technologies," $t(53)=$

Table 4. Descriptive statistics for in-service teachers' views on technology capabilities.

\begin{tabular}{|c|c|c|c|c|}
\hline \multirow[t]{2}{*}{ Views on Technology Capabilities } & \multicolumn{2}{|c|}{$\begin{array}{l}\text { Secondary } \\
(n=26)\end{array}$} & \multicolumn{2}{|c|}{$\begin{array}{l}\text { Tertiary } \\
(n=29)\end{array}$} \\
\hline & Mean & SD & Mean & SD \\
\hline $\begin{array}{l}\text { 14) I have daily access to the internet in } \\
\text { order to complete assignments }\end{array}$ & 3.385 & 0.804 & 3.655 & 0.614 \\
\hline 15) I use the computer often & 3.539 & 0.582 & 3.689 & 0.471 \\
\hline 16) I have high-speed internet connectivity & 3.269 & 1.002 & 3.517 & 0.688 \\
\hline 17) I use the internet often & 3.385 & 0.804 & 3.552 & 0.572 \\
\hline $\begin{array}{l}\text { 18) I can easily upload or download files } \\
\text { from the internet }\end{array}$ & 3.500 & 0.509 & 3.621 & 0.494 \\
\hline $\begin{array}{l}\text { 19) It will be easy to gain access to technic- } \\
\text { al support when I need it }\end{array}$ & 2.769 & 0.815 & 3.241 & 0.786 \\
\hline $\begin{array}{l}\text { 20) I am confident in using the } \\
\text { computer-related technologies }\end{array}$ & 3.039 & 0.599 & 3.483 & 0.634 \\
\hline
\end{tabular}


$-2.664, p=0.010)$.

\subsection{In-Service Teachers' Views on Online/Blended Learning Approach}

Research Question Three: To what extent are there differences in the interest of the in-service teachers in the secondary and tertiary tracks of the PDE programme on online/blended learning approach?

To provide answers to this research question, the participants were asked to indicate their degree of agreement on the seven Likert-type items that measured their views on the online/blended learning approach. See Table 5 for the findings.

As showed in Table 5, the mean values of the seven items ranged from 1.885 to 3.154 for teachers in the secondary track of the PDE programme, while the mean values for those in the tertiary track ranged from 2.379 to 3.414. These values showed that the participants were mostly in agreement in their responses except for item 26 for the secondary group. The findings also showed that the tertiary group generally had higher mean values when compared to the secondary group. The standard deviation values ranged from 0.693 to 0.996 for the secondary track in-service teachers, and from 0.628 to 1.115 for the tertiary group. There were more variations in the responses of the tertiary group.

Further analysis was done with the use of the independent samples $t$-test to determine if there were any statistical differences between the two groups on the seven items that measured online/blended learning. The results showed that there was a significant difference on the first item (number 21), "I am interested in an online and/or blended learning programme," $t(53)=-2.551, p=0.014$.

Table 5. Descriptive statistics for in-service teachers' views on online/blended learning.

\begin{tabular}{|c|c|c|c|c|}
\hline \multirow[t]{2}{*}{ Views on Online/Blended Learning } & \multicolumn{2}{|c|}{$\begin{array}{l}\text { Secondary } \\
(n=26)\end{array}$} & \multicolumn{2}{|c|}{$\begin{array}{l}\text { Tertiary } \\
(n=29)\end{array}$} \\
\hline & Mean & SD & Mean & SD \\
\hline $\begin{array}{l}\text { 21) I am interested in an online/blended } \\
\text { learning programme }\end{array}$ & 2.923 & 0.796 & 3.414 & 0.628 \\
\hline $\begin{array}{l}\text { 22) The online/blended approach will } \\
\text { enable learn without disrupting my job }\end{array}$ & 3.154 & 0.785 & 3.379 & 0.728 \\
\hline $\begin{array}{l}\text { 23) I can determine the direction of my } \\
\text { study with an online/blended approach }\end{array}$ & 3.000 & 0.693 & 3.276 & 0.649 \\
\hline $\begin{array}{l}\text { 24) I can obtain the materials from the } \\
\text { library and internet for learning }\end{array}$ & 3.153 & 0.881 & 3.275 & 0.702 \\
\hline $\begin{array}{l}\text { 25) With the online/blended approach, I } \\
\text { study at my own pace }\end{array}$ & 2.962 & 0.824 & 3.103 & 0.724 \\
\hline $\begin{array}{l}\text { 26) I would want most of my classes to be } \\
\text { online }\end{array}$ & 1.885 & 0.993 & 2.379 & 1.115 \\
\hline $\begin{array}{l}\text { 27) I am concerned about the time needed } \\
\text { for online interaction }\end{array}$ & 3.039 & 0.916 & 2.931 & 0.923 \\
\hline
\end{tabular}




\subsection{Differences in Views Expressed by Male and Female In-Service Teachers}

Research Question Four: To what extent are there differences in the views expressed by the male and female in-service teachers on learner characteristics, technology capabilities, and experiences of online/blended learning approach?

To provide answers to this research question, the participants were asked to indicate their degree of agreement to the 27 Likert-type items that measured differences in the in-service teachers' views on learner characteristics, technological capacities and experiences of online/blended learning approach. The analysis was done by using the total of the subscale values. See Table 6 .

As shown in Table 6, the overall mean values for the three subscales were close. As a result, there were no statistically significant differences $(\alpha \leq 0.05)$ in the views expressed by the male and female in-service teachers on learner characteristics, technological capacities, and experiences of online/blended learning approach.

\subsection{Learning Experiences and Expectations of Online/Blended Learning}

Research Question Five: What are the learning experiences and expectations of the in-service teachers on the online/blended learning approach?

To provide answers to this question, the in-service teachers were asked a combination of closed and open-ended items that measured their learning experiences on the online/blended approach used in the PDE programme. The findings are presented below.

The participants were asked to rate as well as describe their experiences. The ratings were as followings "poor" (12.7\%), "fairly good" (25.5\%), "good" (43.6\%), and "excellent" (18.2\%). A few participants described their experiences by stating the following "it was very demanding," "I found it challenging," "I hate going online," "I feel isolated," "I am not satisfied with the course delivery," and "I am not a big fan of online education."

The participants were asked to state their expectations of participating in a course using the online/blended learning approach. The open-ended responses were analyzed, and the responses were grouped under following themes 1) access to information and facilitators, 2) timely feedback, 3) efficient support system, 4)

Table 6. In-service teachers' views three subscales.

\begin{tabular}{ccccccc}
\hline Subscale & Gender & Mean & SD & $d f$ & $t$-value & Sig. \\
\hline Learner Characteristics & Male & 41.8 & 3.841 & 53 & -0.773 & 0.158 \\
& Female & 42.5 & 3.242 & & & \\
Technological capabilities & Male & 24.5 & 4.148 & 53 & 1.119 & 0.268 \\
& Female & 23.3 & 3.441 & & & \\
Experiences & Male & 24.7 & 4.064 & 53 & 1.074 & 0.288 \\
& Female & 23.2 & 5.173 & & & \\
& & & & & &
\end{tabular}


flexibility in completing tasks, and independent learning.

The participants were also asked to list the advantages and disadvantages of using the online/blended learning approach. For the advantages, the participants stated 1) convenience, 2) reduction in travelling cost, and 3) learning at one's own pace.

For the disadvantages, the following themes emerged from the analysis 1) unavailability of face-to-face interaction, 2) lack of adequate knowledge of how to use the Moodle platform, 3) problems with internet connectivity, 4) power outage, 5) lack of technical support, 6) lack of time management and meeting deadlines, 7) very demanding, 8) vague instructions, 9) large discussion groups, 10) no follow up by lecturers, and 11) lack of opportunities for probing.

\section{Discussion of Results}

The participants were 55 Jamaicans with different characteristics. This is consistent with the views expressed by Dewan and Dewan [45], who stated that previous studies on online learner characteristics showed that they are becoming more diverse. In the current study, nearly half of participants were between the age ranges of 31 to 40 years, indicating that they were adult learners; and findings also showed that approximately $89 \%$ had over one year of work experience. These are consistent with the findings of Castle, Dang, McGuire and Tyler [46] who stated that the average age range for online students in the US is between 30 and 35 years, and Dewan and Dewan [45] who stated that online learners are usually adults who are employed.

Regarding research question one, the findings showed that a high percentage of the participants agreed that they possessed the required characteristics needed for online/blended learning. Some of the characteristics identified in this study included the ability to excel, confidence, not giving up when confronted with technology-related obstacles, comfortable working with online/blended, and comfortable expressing self. The interesting point is that approximately $18 \%$ of the participants disagreed with the statement I organize my time to complete course requirements in a timely manner. This is worth noting because time management is one of the factors impacting online learners ([47] [48]). Apart from time management, other learner characteristics noted by Dewan and Dewan [45] are interpersonal and communication skills, understand and value interaction.

Concerning research question two, the findings showed that the tertiary group had higher mean values when compared to the secondary group. On item 19, It will be easy to gain access to technical support when I need it, the mean value for the secondary group was lower when compared with the tertiary group. This mean difference was noted in the findings of the independence samples $t$-test which showed that there was a significant difference between the two groups," $t(53)=-2.185, p=0.033$. Support for online education is considered essential. Hence, Lowe [49] recommended the need to support online learners since some 
of them are not well prepared for the demand of that mode of learning. This view was also expressed by Fazio, Gilding, and Zorzenon [50].

The findings also showed that there was a significant difference in the view expressed by the secondary and tertiary in-service teachers, "I am confident in using the computer-related technologies," $t(53)=-2.664, p=0.010$. The tertiary group seems to agree strongly about being confident in using computer technologies. This is not surprising since they teach in institutions of higher learning where technological skills are needed. The null hypothesis tested was rejected because there were differences in the views of the in-service teachers in the secondary and tertiary tracks of the PDE programme on technology capabilities needed for online/blended learning.

Regarding research question three, the findings showed that the mean values of the seven items were slightly lower for the teachers in the secondary group when compared to those in the tertiary group. The latter group was mostly in agreement in their views on their interest on online/blended learning approach. The findings also showed that there were more variations in the responses of the tertiary group. Furthermore, the results of the $t$-test only showed a difference on the item, "I am interested in an online/ blended learning programme," $t(53)=$ $-2.551, p=0.014$. Students may be interested in online education for a variety of reasons. Two such reasons are adequate faculty-student interaction and active engagement [51]. This view about active engagement was also expressed by Jones [52].

On research question four, the results of the analyses on the subscales (learner characteristics, technology capabilities, \& experiences), did not reveal any differences in the views of the male and female in-service teachers. Although there were no differences, the male in-service teachers' views were slightly higher with technological capabilities and experiences. No study was found to support this finding.

Regarding research question five, the results showed that approximately 13\% rating their experience as "poor," $26 \%$ "fairly good," $44 \%$ "good," and 18\% "excellent" (18.2\%). The ratings are not surprising. In a study done by Lowenthal, Bauer and Chen [53], students' rating of online courses was lower. Jacob [54] stated that if online experience isolation, "they will not benefit from the course" (p. 10). Jacob [54] recommended having a learning community which would reduce isolation. In the current study, a few participants described their experiences as "it was very demanding," "I found it challenging," "I hate going online," "I feel isolated," "I am not satisfied with the course delivery," and "I am not a big fan of online education." On the issue of satisfaction, Brunto, Brown, Costello, Delaney, Fox, and Galvin [16], were of the view that online students feel unsatisfied due to the kind of experiences they had as well as the quality of instruction they received. Brunto et al. [16] were of the view that for students to succeed in an online environment, they should feel satisfied with the instruction.

The participants' expectations of participating in a course using the on- 
line/blended learning approach included access to information and facilitators, timely feedback, efficient support system, flexibility in completing tasks, and independent learning. Some of the findings were consistent with the views expressed by Corredor [55] who indicated that internet and broadband access are needed for online education. A similar view was expressed by Standford-Bower [56] who also reported computer accessibility, as well as time management, and technical support for student persistence in online learning.

The participants listed the advantages of using the online/blended learning as being convenient, reduction in travelling cost, and learning at one's own pace. The literature shows that online programmes are becoming popular due to their advantages. In a study done by Allen and Seaman ([2] [3] [4]), they noted that accessibility to students, reduced costs for commuting students, among others as the reasons for enrolling in an online programme. Factors such as convenience, flexibility, and time management were echoed as benefits of online learning (Standford-Bower, [56]), while Twigg [57] stressed economic impact (lower cost) to students as an advantage. Jacob [54] is also of the view that feedback from the instructor is very important since it "reinforces the course material and encourages the students to become more engaged in the learning process" (p. 3). Similar views on feedback were also expressed by Fish and Wickersham [58].

For the disadvantages, the participants listed unavailability of face-to-face interaction, lack of adequate knowledge of how to use the Moodle platform, problems with internet connectivity, power outage, lack of technical support, lack of time management and meeting deadlines, very demanding, vague instructions, no follow up by lecturers, and lack of opportunities for probing. Regarding internet connectivity and power outage, as a developing country, the occurrence of these problems is expected. However, of importance is the technical support. According to Standford-Bower [56], inadequate technical support to assist students, poor time management, and lack of contact with the facilitator accessibility issues, among others would impact on students' success and satisfaction with online learning. Lovette [59] also mentioned access to facilitators as a factor for online education, while Bambara et al. [60] stressed incomplete feedback from facilitators as a problem, and Dewan and Dewan [45] made similar observations, by recognizing macro environmental barriers such as a lack of institutional support, lack of connectivity, inadequate hard/software and inadequate technical support.

The participants identified unavailability of face-to-face interaction, lack of knowledge of how to use the technology, problems with internet connectivity and power outage, lack of access to internet, lack of technical support, problems with time management and meeting deadlines, very demanding, vague instructions, large discussion groups, and no follow up by lectures/opportunities for probing as disadvantages. In a study done by Alukp and Hendrikz [61], the participants suggested reducing the number of students per group for better participation. Further training was also recommended for the facilitators. To address 
these issues, several requirements are needed before online delivery can be done successfully. These include understanding the profile of the learners [62], engaging the online learner and providing information [63], and providing adequate support [61], among others.

\section{Conclusion}

This study provides a useful base from which to draw conclusions regarding the views of in-service teachers on the use of online/blended learning approach. The researchers concluded that the in-service teachers had the necessary characteristics needed to do online/blended learning. The findings also suggested that the in-service teachers had the necessary technology capabilities required to succeed in an online/blended learning programme. The findings also showed that the in-service teachers had different experiences with the online/blended learning approach. The in-service teachers identified a number of expectations, benefits, and challenges which were consistent with the literature. The findings showed that there were differences in the views of the in-service teachers in the secondary and tertiary tracks of the PDE programme on technology capabilities needed for online/blended learning, and on online/blended learning. There were no statistically significant differences in the views expressed by the male and female in-service teachers on learner characteristics, technological capacities, and experiences of online/blended learning approach.

\section{Limitations}

As with any research study, three limitations were noted. The first limitation is that the study only focused on the views of in-service teachers through the use of a questionnaire. As a result, triangulation of responses given by the participants could not be confirmed. The second limitation was due to low enrollment in the programme. Data were collected over three-year period. The third limitation was on the small sample size used $(n=55)$. Accordingly, the findings cannot be generalized to all in-service teachers in the PDE programme. Despite these limitations, the significance of the findings cannot be underestimated because of the contribution of the study to the existing literature in the Caribbean and beyond. Despite these limitations, the findings provided insights on the online/blended learning by in-service teachers. However, there is a range of potential future avenues for research in this area. For instance, additional research could build on the limitations, and a bigger sample size could be used in order to yield results that can be more generalisable.

\section{Recommendations}

Based on the findings, the following recommendations are made:

1) Program managers and facilitators should examine and utilize the three guiding principles offered by Pelz [33], for organizing pedagogy for students' success in this environment. 
2) Although the percentage of the in-service teachers who indicated that they possessed the required characteristics needed for online/blended learning, there is a need to ensure that the students are given an orientation programme. This will help them to understand the nature of online learning.

3) Program managers and facilitators should continue to maintain the interest of the in-service teachers in the online/blended programme by trying to minimize the barriers such as ensuring that the students have an adequate knowledge of how to use the technology, have the necessary basic technologies needed, that there are a sufficient number of opportunities for interactions, and availability of technical support.

\section{Conflicts of Interest}

The authors declare no conflict of interest regarding the publication of this paper.

\section{References}

[1] Dahalan, N., Hassan, H. and Atan, H. (2012) Student Engagement in Online Learning: Learners' Attitude to E-Mentoring. Procedia-Social and Behavioral Sciences, 67, 64-476.

[2] Allen, I.E. and Seaman, J. (2006) Making the Grade: Online Education in the United States, 2006. Midwestern Edition, Babson Survey Research Group, the Sloan Consortium, and Midwestern Higher Compact. https://www.onlinelearningsurvey.com/reports/making-the-grade-midwestern.pdf

[3] Allen, I.E. and Seaman, J. (2008) Staying the Course: Online Education in the United States, 2008. Babson Survey Research Group, and the Sloan Consortium. https://www.onlinelearningsurvey.com/reports/staying-the-course.pdf

[4] Allen, I.E. and Seaman, J. (2011) Going the Distance: Online Education in the United States, 2011. Babson Survey Research Group and Quahog Research Group. https://www.onlinelearningsurvey.com/reports/goingthedistance.pdf

[5] Kuh, G.D., Kinzie, J., Schuh, J.H. and Whitt, E.J. (2005) Assessing Conditions to Enhance Educational Effectiveness: The Inventory for Student Engagement and Success. Jossey-Bass, Francisco, CA.

[6] Kentnor, H.E. (2015) Distance Education and the Evolution of Online Learning in the United States. Curriculum and Teaching Dialogue, 17, 34.

https://digitalcommons.du.edu/cgi/viewcontent.cgi?article=1026\&context=law_facp $\mathrm{ub}$

[7] Bailey, M., Gosper, M., Ifenthaler, D., Ware, C. and Kretzschema, M. (2017) On-Campus, Distance or Online? Influences on Student Decision-Making about Study Modes at University. Australasian Journal of Educational Technology, 34, 72-85. https://doi.org/10.14742/ajet.3781

[8] Kokoc, M., Ozlu, A., Cimer, A. and Karal, H. (2011) Teachers' Views on the Potential Use of Online in-Service Education and Training Activities. Turkish Online Journal of Distance Education, 12, 68-87.

https://arastirmax.com/en/system/files/dergiler/43695/makaleler/12/4/arastirmax-te achers-views-potential-use-online-service-education-and-training-activities.pdf

[9] Fullan, M. (2007) The New Meaning of Educational Change. $4^{\text {th }}$ Edition, Teachers College Press, New York. 
[10] Anderson, J. and Glen, A. (2003) Building Capacity of Teachers/Facilitators in Technology-Pedagogy Integration for Improved Teaching and Learning. https://ftp.unpad.ac.id/orari/library/library-ref-eng/ref-eng-3/application/education /unesco/BuildingCapacity.pdf

[11] Dexter, S., Anderson, R.E. and Becker, H.J. (1999) Teachers' Views of Computers as Catalysts for Changes in Their Teaching Practice. Journal of Research on Computing in Education, 31, 221-239. https://doi.org/10.1080/08886504.1999.10782252

[12] Hunt, C. (2011) National Strategy for Higher Education to 2030: Report of the Strategy Group. Department of Education and Skills, Government Publications Office.

http://hea.ie/assets/uploads/2017/06/National-Strategy-for-Higher-Education-2030. pdf

[13] European Commission (2014) Report to the European Commission on New Models of Learning and Teaching in Higher Education. Publications Office of the European Union, Luxembourg. http://ec.europa.eu/education/library/reports/modernisation-universities_en.pdf

[14] Artino, A.R. and Stephens, J.M. (2009) Academic Motivation and Self-Regulation: A Comparative Analysis of Undergraduate and Graduate Students Learning Online. Internet and Higher Education, 12, 146-151. https://doi.org/10.1016/j.iheduc.2009.02.001

[15] Horton, W. (2006) E-Learning Design. $1^{\text {st }}$ Edition, Preifter \& Company, San Francisco, CA.

[16] Brunto, J., Brown, M., Costello, E., Delaney, L., Fox, S. and Galvin, C. (2015) Student Success Toolbox Phase Two Report: Literature Analysis \& Digital Tools Database. National Institute for Digital Learning, Dublin City University, Dublin.

[17] Brunto, J., Brown, M., Costello, E. and Farrell, O. (2018) Pre-Induction Supports for Flexible Learners: The Head Start Online MOOC Pilot: A Practice Report. Student Success, 9, 1-7. https://doi.org/10.5204/ssj.v10i1.434

[18] Ghavifer, S., Razak, A.Z.A., Ghani, M.F.A., Ran, N.Y., Meixi, Y. and Tengyue, Z. (2014) ICT Integration in Education: Incorporation for Teaching and Learning Improvement. The Malaysian Online Journal of Educational Technology, 2, 24-45.

[19] Caldwell, B.J. and Spinks, J.M. (1998) Beyond the Self-Managing School. Falmer, London.

[20] Greenhow, C., Rbelia, C. and Hughes, J. (2009). Learning, Teaching, and Scholarship in a Digital Age. Educational Researcher, 38, 246-259. https://doi.org/10.3102/0013189X09336671

[21] Mbalamula1, Y.S. (2016) Role of ICT in Teaching and Learning: Influence of Lecturers on Undergraduates in Tanzania. Advances in Research, 8, 1-11. https://doi.org/10.9734/AIR/2016/30283

[22] DeGennaro, D. (2008) Learning Design: Analysis of Youth-Initiated Technology Use. Journal of Research on Technology in Education, 41, 1-20. https://doi.org/10.1080/15391523.2008.10782520

[23] Ablion, P. (1999) Self-Efficacy Beliefs as an Indicator of Teachers: Preparedness for Teaching with Technology.

https://pdfs.semanticscholar.org/ba03/fa49bfd9e9975bf93db5ae9ca1af8585e019.pdf

[24] UNESCO (2008) ICT Competency Standards for Teachers: Implementation Guidelines. http://unesdoc.unesco.org/images/0015/00156209E.pdf

[25] Planning Institute of Jamaica (2009) Vision 20130 Information and Communica- 
tion Technology Sector Plan. Kingston.

[26] Eduview (2009) AK-12 Leadership Series. http://www.blackboard.com/resources/k12/Bb_K12_WP_BlendedLearning.pdf

[27] Friedman, T.L. (2006) The World Is Flat: A History of the Twenty-First Century. Farrar, Straus and Giroux, New York.

[28] Burge, E. (2000) The Strategic Use of Learning Technologies. Wiley, New York.

[29] Curtis, B. (2006) Educase Review Online: The Future of Online Teaching and Learning in Higher education. https://er.educause.edu/ /media/files/article-downloads/eqm0644.pdf

[30] Volery, T. and Lord, D. (2000) Critical Success Factors in Online Education. International Journal of Educational Management, 14, 216-223. https://doi.org/10.1108/09513540010344731

[31] Pelz, B. (2004) (My) Three Principles of Effective Online Pedagogy. Journal of Asynchronous Learning Networks, 14, 103-116.

[32] The Institute for Higher Education (2000) Quality on the Line: Benchmarks for Success in Internet-Based Distance Education.

[33] Tobin, T. (2004) Best Practices for Administrative Evaluation of Online Faculty. Online Journal of Distance Learning Administration, 7, ERIC No. EJ1114201.

[34] Leedy, P.D. and Ormrod, J.E. (2016) Practical Research: Planning and Design. 11th Edition, Pearson Merrill Prentice Hall, Upper Saddle River.

[35] Gall, M.D., Gall, J.P. and Borg, W.R. (2007) Educational Research: An Introduction. 8th Edition, Pearson Education Inc., Boston.

[36] Babbie, E.R. (2016) The Practice of Social Research. 14th Edition, Cengage Learning, Belmont.

[37] Dray, B.J. and Miszkiewicz, M. (2010) Online Learning Readiness Survey (OLRS). Regents of the University of Colorado and Buffalo State College.

[38] Dray, B.J., Lowenthal, P.R., Miszkiewicz, M.J., Ruiz-Primo, M.A. and Marczynski, K. (2011) Developing an Instrument to Assess Student Readiness for Online Learning: A Validation Study. Distance Education, 32, 29-47. https://doi.org/10.1080/01587919.2011.565496

[39] Bland. J. and Altman, D. (1997) Statistics Notes: Cronbach's Alpha. BMJ, 314, 572. https://doi.org/10.1136/bmj.314.7080.572

[40] DeVellis, R. (2003) Scale Development: Theory and Applications. Sage, Thousand Oaks.

[41] Nunnally, J. and Bernstein, L. (1994) Psychometric Theory. McGraw-Hill Higher Inc., New York.

[42] Cerny, C.A. and Kaiser, H.F. (1977) A Study of a Measure of Sampling Adequacy for Factor-Analytic Correlation Matrices. Multivariate Behavioral Research, 12, 43-47. https://doi.org/10.1207/s15327906mbr1201_3

[43] Kaiser, H. (1974) An Index of Factor Simplicity. Psychometrika, 39, 31-36. https://doi.org/10.1007/BF02291575

[44] Mohajan, H.K. (2017) Roles of Communities of Practice for Development of the Society. Journal of Economic Development, Environment and People, 6, 27-46.

[45] Dewan, S. and Dewan, D. (2010) Distance Education Teachers as a Leader: Learning from the Path Goal Leadership Theory. MERLOT Journal of Online Learning and Teaching, 6, 673-685.

[46] Castle, S.R., Dang, B., McGuire, C.J. and Tyler C.E. (2007) Online Education: Con- 
siderations of Andragogy vs Pedagogy. Proceedings of the Conference on Redesigning Pedagogy Conference: Culture, Knowledge and Understanding, The Centre for Research in Pedagogy and Practice (CRPP), Singapore, 28-30 May 2007.

[47] Barbera, E. and Reimann, P. (2013) Assessment \& Evaluation of Time Factors in Online Teaching and Learning. Information Science Reference, USA.

[48] Sellers, E. (n.d.). Poor Time Management in Online Learning. https://education.seattlepi.com/poor-time-management-online-learning-1435.html

[49] Lowe, S.D. (2005) Responding to Learner Needs in Distance Education: Providing Academic and Relational Support (PARS). In: Levin, S.J., Ed., Making Distance Education Work: Understanding Learning and Learners at a Distance, Learners Association, Okemos, 73-87.

[50] Fazio, T.D., Gilding, A. and Zorzenon, G. (2001) Student Learning Support in an Online Learning Environment. http://www.ascilite.org/conferences/coffs00/papers/teresa_defazio.pdf

[51] Sarder, B. (2014) Improving Student Engagement in Online Courses, 2014 ASEE Annual Conference \& Exposition, Indianapolis, 15-18 June 2014. file://C:/Users/?Cynthia/Downlads/Student_Engement_Sarder.pdf

[52] Jones, R.D. (2008) Strengthening Student Engagement. International Center for Leadership in Education.

http://www.cesdp.nmhu.edu/prof-learning/docs/Teaching\%20and\%20Learning/Stu dent\%20Engagement/Strengthen\%20Student\%20Engagement $\% 20$ white\%20paper.p df

[53] Lowenthal, P., Bauer, C. and Chen, K. (2015) Student Perceptions of Online Learning: An Analysis of Online Course Evaluations. Journal of Distance Education, 29, 85-97. https://doi.org/10.1080/08923647.2015.1023621

[54] Jacob, P. (2013) The Challenges of Online Courses for the Instructor. Research in Higher Education Journal, 21, 1-18. http://www.aabri.com/manuscripts/131555.pdf

[55] Corredor, J. (2006) General and Domain-Specific Influence of Prior Knowledge on Setting of Goals and Content Use in Museum Websites. Computers and Education, 47, 207-221. https://doi.org/10.1016/j.compedu.2004.10.010

[56] Standford-Bower, D.E. (2008) Persistence in Online Classes: A Study of Perceptions among Community College Stakeholders. MERLOT Journal of Online Learning \& Teaching, 4, 37-50.

http://www.westga,edu/ distance/ojdla/summer72/tobin72.html

[57] Twigg, C. (2001) Innovations in Online Learning: Moving Beyond no Significant Difference. http://www.thencat.org/Monographs/Mono4.pdf

[58] Fish, W.E. and Wickersham, L.E. (2010) Best Practices for Online Instructors. The Quarterly Review of Distance Education, 10, 279-284.

[59] Lovett, M. (2001) A Collaborative Convergence on Studying Reasoning Processes: A Case Study in Statistics. In: Carver, S. and Klahr, D., Eds., Cognition \& Instruction: 25 Years of Progress, Lawrence, Erlbaum, 347-384.

[60] Bambara, C.S., Harbour, C.P., Davies, T.G. and Athey, S. (2009) Delicate Engagement: The Lived Experiences of Community College Students Enrolled in High-Risk Online Courses. Community College Review, 36, 219-238. https://doi.org/10.1177/0091552108327187

[61] Alukp, R. and Hendrikz, J. (2012) Supporting Distance Students: The Pilot Study of a Tutorial Model and Its Impact on Students' Performance. Progressio, 34, 68- 83.

[62] Bocchi, J., Eastman, J.K. and Swift, C.O. (2000) Retaining the Online Learner: Profile of Students in an Online MBA Programme and Implications for Teaching 
Them. Journal of Education for Business, 79, 245-253.

https://doi.org/10.3200/JOEB.79.4.245-253

[63] Bradford, G. and Wyatt, S. (2010) Online Learning and Student Satisfaction: Academic Standing, Ethnicity and Their Influence on Facilitated Learning, Engagement, and Information Fluency. Internet and Higher Education, 13, 108-114. https://www.learntechib.org/p/108388/ https://doi.org/10.1016/j.iheduc.2010.02.005

\section{Appendix}

Faculty of Education \& Liberal Studies.

University of Technology, Jamaica.

Dear Participant,

\section{Re: Invitation to Participate in a Research Study}

You have been selected to participate in a study designed to examine the learner characteristics, experiences, and technological capacities possessed by in-service teachers pursuing postgraduate studies using the online/blended learning approach at a teacher training institution in Jamaica.

If you volunteer to participate in this study, you will be required to complete a questionnaire which should take no more than 10 minutes. If you do not want to be involved in this study, please do not complete the survey.

If you agree to participate but later decide to withdraw your participation, you have the right to do so without penalty. Also note that only Dr. Onyefulu and Dr. Roofe have access to the dataset. All individual responses will be confidential and anonymous.

Please note that the researchers have already applied for research ethics clearance from the Research Ethics Committee at the University of Technology, Jamaica.

If you have any questions or concerns about the research, please feel free to contact me by email at conyefulu@utech.edu.jm. I would appreciate your responding by January 16, 2017.

Thank you in advance.

Sincerely,

Cynthia Onyefulu, PhD 